\title{
Course in E-learning and Moodle for Academic Staff - Development, Provision, Evaluation, Satisfaction
}

\author{
Angelina Kirkova-Bogdanova \\ Medical University of Plovdiv, Faculty of Public Health, Department of Medical Informatics, \\ Biostatistics and E-learning, 15A Vasil Aprilov Blvd., 4002 Plovdiv, Bulgaria
}

\begin{abstract}
The COVID-19 pandemic created challenges for education systems. Many university lecturers did not have enough training to teach in an electronic environment, for others there was no such experience at all. This paper discusses the evaluation of a course "E-learning. Moodle." designed to prepare faculty to teach online and users' satisfaction with the training. The influence of demographic and professional factors was analysed. Results indicate that confidence in computer skills and pedagogical qualification are strong predictors of the success of such training. Micro-learning with short video clips is most suitable.
\end{abstract}

Keywords - e-learning, training, faculty, Moodle.

\section{Introduction}

The last two academic years have been an emergency all over the world. The COVID-19 pandemic created challenges and difficulties for education systems.

DOI: 10.18421/TEM104-29

https://doi.org/10.18421/TEM104-29

Corresponding author: Angelina Kirkova-Bogdanova, Medical University of Plovdiv, Faculty of Public Health, Department of Medical Informatics, Biostatistics and Elearning, 15A Vasil Aprilov Blvd., 4002 Plovdiv, Bulgaria.

Email: angelina.kirkova@mu-plovdiv.bg

Received: 10 August 2021.

Revised: 06 October 2021.

Accepted: 14 October 2021.

Published: 26 November 2021.

(cc) BY-NC-ND(C) 2021 Angelina Kirkova-Bogdanova; published by UIKTEN. This work is licensed under the Creative Commons Attribution-NonCommercial-NoDerivs 4.0 License.

The article is published with Open Access at www.temjournal.com
The urgent and sudden transition to distance training was a stress especially for healthcare education, where practical skills are mastered in the laboratories and at the bed of the patient. Although elearning is no longer a novelty and higher educational institutions are on the path of introducing e-forms of training according to the specifics of scientific fields and the characteristics of students, the time to move entirely to distance learning was extremely short.

Academic staff predetermines the effective exploitation of an e-learning platform and their fears and concerns should be faced on every stage of the provision of e-learning on a LCMS - from the creation of digital content to the final assessment of students.

Faculty of higher education institutions must be provided with support and training as they adapt to the new normal in the higher education landscape and embrace the instructional challenges brought by the COVID-19 pandemic [1].

Many university lecturers did not have enough training and experience to teach in an electronic environment, for others, there was no such experience at all. Major obstacles for e-learning activities before the pandemic were lack of time [2] and support [3], [4], and insufficient skills to create quality interactive e-materials and to work in an elearning platform [5], [6]. Providing an appropriate educational environment is of uppermost importance in the transfer of new educational technologies in humanitarian education. Along with providing and maintaining distance learning software, methodological support for teachers was the next most important task for e-learning centres at universities. The rapid transition to online learning in response to the COVID-19 pandemic pushed fast consideration of how teachers were trained to teach online [7]. Intensive training of university faculty members in the employment of the LMS is an optimal way to increase the effectiveness in teaching and learning [8]. At the Medical University of Plovdiv, this task was solved through short kick-off 
face-to-face training in March 2020, publication of training materials, algorithms and instructions and through an e-course in Moodle entitled "E-learning. Moodle". Knowing the factors that influence teachers' perception, evaluation and satisfaction, we can refine the design of learning to improve its personalization and focus on the learner. This paper discusses the development, the provision and the evaluation of the course "E-learning. Moodle" by the users.

\section{Background}

Software solutions for distance training were offered to the academic staff at the Medical University of Plovdiv. Distance learning during lockdown periods was conducted through MSOffice (MSTeams, MSForms, SharePoint predominantly), Moodle, and few other applications.

The course "E-learning. Moodle" was developed in the summer of 2021 following the instructional design principles and it was launched at the beginning of the 2020/2021 academic year, which was also marked by long periods of lockdown. The training was developed as a course in Moodle - the formal learning content management system at the Medical University of Plovdiv. Thus, faculty has the opportunity to experience being an e-student, which will help to gain a better understanding of both the difficulties that students would face and their expectations. The training combines competencies from the relevant subject area of each participant with pedagogical and technological knowledge and skills because effective online teaching requires the integration of knowledge in technology and pedagogy [9]. The objective was for the participants in the course to acquire basic knowledge and skills for creating e-learning content and working with the learning content management system Moodle. To meet the objective, seven topics were developed:

1. E-learning

2. Instructional design

3. E-learning content - best practices

4. LCMS Moodle

5. LCMS Moodle - test module

6. LCMS Moodle - lesson module

7. Content protection.

The summary of each topic comprised an abstract and learning outcomes. Every module started with a description of the types of resources and activities used in it. Though the training was initially designed for distance asynchronous learning, we had a synchronous lesson in MSTeams in each topic at the request of the colleagues. The records of the meetings were published as resources.

The design provided maximum independent asynchronous learning and allowed participants to manage learning on their own, i.e., to choose resources and activities - all topics were visible. Micro-learning is appropriate for this audience, so resources were short and not excessive. The participants could generate content, thus they transferred their expert and pedagogic experience in their learning and linked their area of expertise with the new knowledge and skills. Some specific strategies were: to avoid a sense of mentoring, the role "student" was renamed to "participant" as the course was designed for the colleagues and I wished to encourage dialogue and discussion as appropriate andragogic techniques; assignments and tests were not obligatory thus not graded, but commented in private; colour coding - the names of types of resources and activities appeared in the same colour everywhere in the course for gaining attention and better understanding these in a context; using a variety of resources and activities to demonstrate their application in practice; explanation of the resources and activities used in each topic in a label at the beginning, including reasoning why they had been chosen; practical skills trained through short animated videoclips that opened in a new smaller window to enable learners to practice the skill while watching the video; publication of references to external sources; examples from the healthcare domain; open questions and underdeveloped ideas to provoke critical thinking and bringing professional experience in understanding the matter.

Evaluation of training is mandatory in instructional design. It is valuable feedback for improvement and upgrades. I conducted a pilot evaluation of the ecourse through an anonymous questionnaire.

This study aimed to analyse the feedback from the pilot evaluation and to investigate the satisfaction of the participants with the conducted training. The influence of demographic and professional factors age, gender, prior experience with Moodle courses, pedagogic qualification, computer skills selfassessment was studied.

\section{Methods and Participants}

The study was carried out through a self-reported online (Google Forms) anonymous survey among academic staff training healthcare majors at the Medical University of Plovdiv. The evaluation form was published in December 2020 and stayed opened until the end of the academic year - June 2021. The questionnaire was designed specifically for this investigation.

A total of 109 teachers were enrolled, of them, 92 took part in the training. The number of colleagues, who completed the questionnaire was 69. The estimated margin of error (confidence interval) at a confidence level of $95 \%$ was $5.93 \%$ [10].

The evaluation instrument contained:

- an evaluation section - 25 statements with agreement measured on a five-point Likert scale: 
from 1 (definitely disagree) to 5 (definitely agree);

- a satisfaction section - 17 statements with agreement measured on a five-point Likert scale: from 1 (definitely disagree) to 5 (definitely agree).

- section of factor variables - age, gender, prior experience with Moodle courses, pedagogic qualification, computer skills self-assessment;

- questions about the perceived usefulness of the resources, measured on a five-point Likert scale; adaptation to distance training; plans.

Statistical analyses were performed. Ordinal variables, measured on Likert scales, were tested by the non-parametric methods of Kruskal-Wallis and Mann-Whitney. Pearson $\chi^{2}$ test was used for nominal data analyses. Spearman correlation coefficient $r_{s}$ was estimated for ordinal data and interval data without normal distribution.

We accepted a level of significance $\alpha=0.05$.

Central tendencies are presented by a mean value (M) and a standard deviation (SD). The statistical processing of the data was done with IBM SPSS v.19.

\section{Results}

Women dominated among the respondents: $n=61$, $88.41 \%$. The mean age of the participants was $\mathrm{M}=49.76 \pm 8.33$ years. Colleagues, who did not have Moodle courses before the pandemic were $n=49$, $71.01 \%$. More than half of the teachers, $n=38$, $55.07 \%$, had additional pedagogic competence. Participants consider their computer literacy to be good $\mathrm{M}=3.42 \pm 0.99$, only two of them, $2.90 \%$, selfassess their computer skills as poor and ten colleagues, $14.49 \%$, declare excellent skills. Gender has no statistically significant influence on the selfassessment of skills. A statistically significant low negative correlation was found between this variable and age: $r_{\mathrm{s}}=-0.473, \mathrm{P}<0.0001$.

The majority, $\mathrm{n}=48,69.57 \%$, stated they "switched" to distance learning easily. Statistically significant impact on adaptation to "the new normal" teaching had age $-\mathrm{P}=0.003$, as younger colleagues, $\mathrm{M}=47.57 \pm 8.32$ years, declared they got used to it easily. The mean age of those, who answered with "no" to this question was $M=54.43 \pm 6.28$. Another factor with a statistical significance for the adaptation to the different mode of working was computer literacy self-assessment $-\mathrm{P}<0.0001$. Teachers, who had no difficulties in adaptation stated a higher selfassessment, $\mathrm{M}=3.79 \pm 0.82$, compared to the other group with self-assessment of computer skills $\mathrm{M}=2.57 \pm 0.81$. The pedagogic qualification also influenced this variable with a statistical power $\mathrm{P}=0.003$. Nearly half of the staff without pedagogic competence, $\mathrm{n}=16,51.61 \%$, "switched" to distance learning easily, and $n=32,84.21 \%$ did that within the colleagues with a pedagogic qualification.

The majority of the respondents, $n=58,86.57 \%$, answered that they get support from their colleagues to cope with distance learning. The relative share of those who declare that they will maintain a course in Moodle after the pandemic is large $-\mathrm{n}=50,72,46 \%$.

\subsection{Evaluation of the e-Course}

The Cronbach's Alpha reliability test of the evaluation scale (Table 1.) before the analysis of the results showed $\alpha=0.983$. All 69 respondents graded all 25 assertions. Table 1. presents evaluation scores by indicators.

Table 1. Pilot evaluation of the course "E-learning. Moodle" by indicators

\begin{tabular}{|c|c|c|}
\hline$N$ & Indicator & $M \pm S D$ \\
\hline 1. & The course objec & $4.48 \pm 0.797$ \\
\hline 2. & The course objectives are relevant. & $4.54 \pm 0.719$ \\
\hline 3. & Learning outcomes are clear. & $4.55 \pm 0.654$ \\
\hline 4. & $\begin{array}{l}\text { The learning objectives are } \\
\text { relevant. }\end{array}$ & $4.49 \pm 0.656$ \\
\hline 5. & $\begin{array}{l}\text { The topics have a logical } \\
\text { sequence. }\end{array}$ & $4.23 \pm 0.987$ \\
\hline 6. & $\begin{array}{l}\text { The topics are presented clearly } \\
\text { and comprehensibly. }\end{array}$ & $4.46 \pm 0.815$ \\
\hline 7. & $\begin{array}{l}\text { The topics are designed to } \\
\text { contribute to the achievement of } \\
\text { the learning objectives. }\end{array}$ & $4.41 \pm 0.896$ \\
\hline 8. & $\begin{array}{l}\text { The course design is plain and } \\
\text { logical. }\end{array}$ & $4.23 \pm 1.017$ \\
\hline 9. & $\begin{array}{l}\text { The course design contributes to } \\
\text { achieving the learning outcomes. }\end{array}$ & $4.23 \pm 1.073$ \\
\hline 10. & $\begin{array}{l}\text { The course design supports } \\
\text { learning. }\end{array}$ & $4.25 \pm 0.991$ \\
\hline 11. & $\begin{array}{l}\text { The content is interesting and } \\
\text { motivating. }\end{array}$ & $4.09 \pm 1.054$ \\
\hline 12. & $\begin{array}{l}\text { The necessary information is } \\
\text { easily found. }\end{array}$ & $4.23 \pm 0.942$ \\
\hline 13. & $\begin{array}{l}\text { The content is clear and } \\
\text { comprehensible. }\end{array}$ & $4.23 \pm 0.987$ \\
\hline 14. & The content is easily assimilated. & $3.88 \pm 1.092$ \\
\hline 15. & $\begin{array}{l}\text { The colour scheme is suitable for } \\
\text { attracting attention and retention. }\end{array}$ & $4.38 \pm 0.730$ \\
\hline 16. & The texts are easy to read. & $4.43 \pm 0.757$ \\
\hline 17. & re long & $4.33 \pm 0.610$ \\
\hline 18. & The images are informative. & $4.46 \pm 0.608$ \\
\hline 19. & $\begin{array}{l}\text { The images are clear and } \\
\text { comprehensible. }\end{array}$ & $4.43 \pm 0.776$ \\
\hline 20. & The video clips are informative. & $4.52 \pm 0.609$ \\
\hline 21 & $\begin{array}{l}\text { The video clips are clear and } \\
\text { comprehensible. }\end{array}$ & $4.55 \pm 0.607$ \\
\hline 22. & The interface is friendly. & $4.22 \pm 0.921$ \\
\hline 23. & The navigation is convenient. & $4.13 \pm 0.922$ \\
\hline 24 & $\begin{array}{l}\text { The course design allows distance } \\
\text { learning. }\end{array}$ & $4.35 \pm 0.937$ \\
\hline 25. & I liked the course. & $4.43 \pm 0.931$ \\
\hline
\end{tabular}


Statistically significant Spearman correlations between age and indicators grades were not found. I found a statistically significant positive low to moderate correlation between computer literacy selfassessment and indicator grades, except for assertions about colour coding, images and videoclips, where the correlations were negligible.

Prior experience with Moodle courses did not affect evaluation but pedagogic qualification had a statistically significant impact on all but one indicator. Colleagues with a pedagogic background gave higher grades (Table 2.).

Table 2. Impact of pedagogic background on evaluation by indicators

\begin{tabular}{|c|c|c|c|}
\hline \multirow[t]{2}{*}{$N$} & $\begin{array}{c}\text { Staff without } \\
\text { pedagogic } \\
\text { background }\end{array}$ & $\begin{array}{c}\text { Staff with } \\
\text { pedagogic } \\
\text { background }\end{array}$ & \multirow[t]{2}{*}{$P$} \\
\hline & $M \pm S D$ & $M \pm S D$ & \\
\hline 1. & $4.03 \pm 0.948$ & $4.84 \pm 0.370$ & $<0.0001$ \\
\hline 2. & $4.16 \pm 0.860$ & $4.84 \pm 0.370$ & $<0.0001$ \\
\hline 3. & $4.26 \pm 0.773$ & $4.79 \pm 0.413$ & 0.002 \\
\hline 4. & $4.26 \pm 0.773$ & $4.68 \pm 0.471$ & 0.017 \\
\hline 5. & $3.61 \pm 1.116$ & $4.74 \pm 0.446$ & $<0.0001$ \\
\hline 6. & $4.06 \pm 0.998$ & $4.79 \pm 0.413$ & $<0.0001$ \\
\hline 7. & $3.94 \pm 1.093$ & $4.79 \pm 0.413$ & $<0.0001$ \\
\hline 8. & $3.61 \pm 1.174$ & $4.74 \pm 0.446$ & $<0.0001$ \\
\hline 9. & $3.55 \pm 1.234$ & $4.79 \pm 0.413$ & $<0.0001$ \\
\hline 10. & $3.65 \pm 1.142$ & $4.74 \pm 0.446$ & $<0.0001$ \\
\hline 11. & $3.55 \pm 1.234$ & $4.53 \pm 0.603$ & 0.001 \\
\hline 12. & $3.68 \pm 1.077$ & $4.68 \pm 0.471$ & $<0.0001$ \\
\hline 13. & $3.55 \pm 1.060$ & $4.79 \pm 0.413$ & $<0.0001$ \\
\hline 14. & $3.23 \pm 1.087$ & $4.42 \pm 0.758$ & $<0.0001$ \\
\hline 15. & $4.13 \pm 0.806$ & $4.58 \pm 0.599$ & 0.016 \\
\hline 16. & $4.19 \pm 0.946$ & $4.63 \pm 0.489$ & 0.054 \\
\hline 17. & $4.03 \pm 0.605$ & $4.58 \pm 0.500$ & $<0.0001$ \\
\hline 18. & $4.06 \pm 0.574$ & $4.79 \pm 0.413$ & $<0.0001$ \\
\hline 19. & $4.06 \pm 0.929$ & $4.74 \pm 0.446$ & 0.001 \\
\hline 20. & $4.19 \pm 0.654$ & $4.79 \pm 0.413$ & $<0.0001$ \\
\hline 21. & $4.13 \pm 0.619$ & $4.89 \pm 0.311$ & $<0.0001$ \\
\hline 22. & $3.71 \pm 1.071$ & $4.63 \pm 0.489$ & $<0.0001$ \\
\hline 23. & $3.52 \pm 0.962$ & $4.63 \pm 0.489$ & $<0.0001$ \\
\hline 24. & $3.81 \pm 1.108$ & $4.79 \pm 0.413$ & $<0.0001$ \\
\hline 25. & $3.87 \pm 1.118$ & $4.89 \pm 0.311$ & $<0.0001$ \\
\hline
\end{tabular}

I asked the participants to rate the resources according to their perceived usefulness from 1 (useless) to 5 (very useful). Table 3. presents the results.

Table 3. Ranking the resources in the course according to their perceived usefulness

\begin{tabular}{||lc|}
\hline \multicolumn{1}{|c|}{ Resource } & $M \pm S D$ \\
\hline Videoclips & $4.45 \pm 0.796$ \\
Meeting records & $4.23 \pm 1.017$ \\
Lesson & $4.03 \pm 1.029$ \\
Texts & $3.97 \pm 1.000$ \\
\hline
\end{tabular}

No statistically significant Spearman correlation was found between perceived usefulness of resources and age but there were statistically significant low positive correlations of the resources ranks and computer literacy self-assessment. Gender and prior experience with a Moodle course before the pandemic did not have an impact on these variables. Statistically significant differences of perceived usefulness of the four types of published resources were established between pedagogically qualified colleagues and those who are not. Teachers with pedagogic competence gave a higher score for usefulness to all four investigated resources with statistical significances as follows: texts $-\mathrm{P}=0.012$; videoclips $-\mathrm{P}=0.003$; meeting records $-\mathrm{P}=0.004$; lesson $-\mathrm{P}=0.017$.

\subsection{Satisfaction with the e-Course}

I asked the colleagues to rank their agreement with 17 assertions about how the course helped them in their academic duties. The Cronbach's Alpha for this section of the survey was estimated at $\alpha=0.969$. The results are given in Table 4.

Table 4. Academic staff's satisfaction with the course " $E$ learning. Moodle".

\begin{tabular}{|c|c|c|}
\hline$N$ & $\begin{array}{l}\text { Assertions: } \\
\text { The course helped me to: }\end{array}$ & $M \pm S D$ \\
\hline & $\begin{array}{l}\text { feel more confident to maintain a } \\
\text { course in Moodle. }\end{array}$ & $4.09 \pm 1.025$ \\
\hline 2. & feel more confident in online teaching. & $4.06 \pm 1.042$ \\
\hline 3. & $\begin{array}{l}\text { feel more satisfied with online } \\
\text { teaching. }\end{array}$ & $3.55 \pm 1.278$ \\
\hline 4. & $\begin{array}{l}\text { change in a positive direction your } \\
\text { view on the applicability of e-learning } \\
\text { in pregraduate healthcare education. }\end{array}$ & $3.49 \pm 1.279$ \\
\hline 5. & $\begin{array}{l}\text { answer to the educational needs of the } \\
\text { students in an online environment. }\end{array}$ & $3.83 \pm 0.999$ \\
\hline 6. & $\begin{array}{l}\text { create a course in which students feel } \\
\text { comfortable. }\end{array}$ & $3.70 \pm 1.047$ \\
\hline 7. & $\begin{array}{l}\text { create an environment for active } \\
\text { learning. }\end{array}$ & $3.78 \pm 0.968$ \\
\hline 8. & create interactive learning content. & $3.77 \pm 0.987$ \\
\hline 9. & $\begin{array}{l}\text { create different activities and learning } \\
\text { resources in different formats. }\end{array}$ & $3.90 \pm 0.987$ \\
\hline 10. & $\begin{array}{l}\text { optimize your preparation time for } \\
\text { online teaching. }\end{array}$ & $3.41 \pm 1.217$ \\
\hline 11. & $\begin{array}{l}\text { improve virtual communication with } \\
\text { the students. }\end{array}$ & $3.55 \pm 1.301$ \\
\hline 12. & $\begin{array}{l}\text { understand the functionalities of the } \\
\text { learning platform. }\end{array}$ & $4.25 \pm 0.793$ \\
\hline 13. & $\begin{array}{l}\text { improve the effectiveness of online } \\
\text { teaching. }\end{array}$ & $3.78 \pm 1.041$ \\
\hline 14. & $\begin{array}{l}\text { combine andragogical methods with } \\
\text { appropriate technologies. }\end{array}$ & $3.46 \pm 1.023$ \\
\hline 15 & $\begin{array}{l}\text { select the appropriate resources and } \\
\text { activities for your subject area. }\end{array}$ & $3.74 \pm 1.024$ \\
\hline 16. & design and create e-learning units. & $3.90 \pm 0.789$ \\
\hline 17. & $\begin{array}{l}\text { design and create an assessment in } \\
\text { Moodle. }\end{array}$ & $4.19 \pm 0.772$ \\
\hline
\end{tabular}


I found statistically significant low to moderate negative correlations with age and low to moderate positive correlations with computer literacy selfassessment. Spearman correlation coefficients with statistical powers are given in Table 5.

Table 5. Correlations of age and computer literacy selfassessment with satisfaction with the course "E-learning. Moodle”

\begin{tabular}{|ccccc|}
\hline \multirow{3}{*}{$N$} & \multicolumn{2}{c}{ Age } & \multicolumn{2}{c|}{$\begin{array}{c}\text { Computer literacy self- } \\
\text { assessment }\end{array}$} \\
\cline { 2 - 5 } & $r_{s}$ & $P$ & $r_{s}$ & $P$ \\
\hline 1. & -0.539 & $<0.0001$ & 0.521 & $<0.0001$ \\
2. & -0.333 & 0.007 & 0.554 & $<0.0001$ \\
3. & -0.430 & $<0.0001$ & 0.546 & $<0.0001$ \\
4. & -0.330 & 0.007 & 0.342 & 0.004 \\
5. & -0.413 & 0.001 & 0.454 & $<0.0001$ \\
6. & -0.295 & 0.017 & 0.444 & $<0.0001$ \\
7. & -0.476 & $<0.0001$ & 0.526 & $<0.0001$ \\
8. & -0.351 & 0.004 & 0.501 & $<0.0001$ \\
9. & -0.251 & 0.043 & 0.400 & 0.001 \\
10. & -0.380 & 0.002 & 0.290 & 0.016 \\
11. & -0.382 & 0.002 & 0.341 & 0.004 \\
12. & -0.469 & $<0.0001$ & 0.264 & 0.028 \\
13. & -0.495 & $<0.0001$ & 0.490 & $<0.0001$ \\
14. & -0.433 & $<0.0001$ & 0.449 & $<0.0001$ \\
15. & -0.362 & 0.003 & 0.443 & $<0.0001$ \\
16. & -0.558 & $<0.0001$ & 0.378 & 0.001 \\
17. & -0.552 & $<0.0001$ & 0.619 & $<0.0001$ \\
\hline
\end{tabular}

Gender and prior experience with Moodle did not affect satisfaction. Pedagogic competence was a predictor of satisfaction levels for most of the statements (Table 6.).

Table 6. Impact of pedagogic background on satisfaction by assertions

\begin{tabular}{|cccc|}
\hline \multirow{2}{|c}{$\begin{array}{c}\text { Staff without } \\
\text { pedagogic } \\
\text { background }\end{array}$} & $\begin{array}{c}\text { Staff with } \\
\text { pedagogic } \\
\text { background }\end{array}$ & $P$ \\
\cline { 2 - 3 } & $M \pm S D$ & $M \pm S D$ & \\
\hline 1. & $3.61 \pm 1.283$ & $4.47 \pm 0.506$ & 0.009 \\
2. & $3.48 \pm 1.235$ & $4.53 \pm 0.506$ & $<0.0001$ \\
3. & $2.94 \pm 1.504$ & $4.05 \pm 0.769$ & 0.001 \\
4. & $3.19 \pm 1.493$ & $3.74 \pm 1.032$ & 0.143 \\
5. & $3.55 \pm 0.995$ & $4.05 \pm 0.957$ & 0.021 \\
6. & $3.06 \pm 0.998$ & $4.21 \pm 0.777$ & $<0.0001$ \\
7. & $3.45 \pm 1.091$ & $4.05 \pm 0.769$ & 0.014 \\
8. & $3.29 \pm 1.101$ & $4.16 \pm 0.679$ & 0.001 \\
9. & $3.45 \pm 1.091$ & $4.26 \pm 0.724$ & 0.001 \\
10. & $2.87 \pm 1.204$ & $3.84 \pm 1.053$ & 0.001 \\
11. & $2.87 \pm 1.477$ & $4.11 \pm 0.798$ & 0.001 \\
12. & $4.23 \pm 0.956$ & $4.26 \pm 0.644$ & 0.704 \\
13. & $3.39 \pm 1.174$ & $4.11 \pm 0.798$ & 0.007 \\
14. & $3.00 \pm 1.125$ & $3.84 \pm 0.754$ & 0.001 \\
15. & $3.16 \pm 1.068$ & $4.21 \pm 0.704$ & $<0.0001$ \\
16. & $3.71 \pm 0.864$ & $4.05 \pm 0.695$ & 0.090 \\
17. & $3.97 \pm 0.912$ & $4.37 \pm 0.589$ & 0.070 \\
\hline \hline
\end{tabular}

\section{Discussion}

I investigated the academic staff's evaluation of the course "E-learning. Moodle", their satisfaction with the training, and the impact of some demographic and professional factors.

Most of the colleagues did not encounter significant difficulties in the transition to distance learning, but for nearly a third of them, $30.43 \%$, this did not happen easily. This group was dominated by older participants and colleagues with lower selfesteem in computer skills. Surprisingly, prior experience with e-courses had not helped to make it easier to adapt to "the new normal teaching" but it turned out to be more difficult for faculty without additional pedagogic qualifications.

Teachers who are prepared to combine pedagogical and technological competencies in their subject area cope more easily with the challenge of teaching in a virtual environment. As Yousaf, Shehzadi, and Aali state, when training is effective, teachers can make effective use of the learning content management system [11].

The results testify that the conducted training was successful - the evaluation grades of all indicators were positive. The highest scores were given for clear learning outcomes and clear and comprehensible video clips. The unambiguity and clarity of the learning outcomes for each topic guarantee that participants are well informed about the purpose of the topic and they can choose whether to take it or not. Short multimedia pieces of training targeting a specific practical skill as videoclips are effective and it is satisfactory that they have achieved their goal in the course. The ease of learning the material was rated the lowest. This is the only indicator rated below 4 (agree). A possible explanation is that the course refers to an area that, although popular, is outside the scope of the participants' expertise. The content matter experts encounter new terms and formulations in the context of teaching in a learning content management system. The same dependencies, which I found in adaptation to distance learning are also detected in the evaluation of the e-course. As ranking is directly connected with the perceived usefulness of the training, we may assume that the e-course has been more applicable and profitable for colleagues who feel confident with computers and for those who have a pedagogic background. This notion is confirmed by the score for "I liked the course.", which was the highest within the group of teachers with pedagogic background, and, on the contrary, this statement received a score below 4 (agree) by the colleagues who are not prepared in pedagogy (Table 2.). Of course, the aim is not only to get a high appreciation for the course and the likes of the 
colleagues, but the goal is also to guide on improving training. The feedback received shows that the content in the course needs to be made easier to learn. Some ways to achieve this are: to make a glossary - so, on the one hand, each term will be contextually explained, on the other hand, we will demonstrate the activity "glossary"; to make content more detailed and well explained; to add more examples illustrating pedagogical methods applied in an electronic course in Moodle in health disciplines. Also, wherever an idea, procedure or action can be explained by a short video clip, this should be done. In addition to the evaluation scale, the videoclips received the highest perceived usefulness rating of all other resources. Next come meeting recordings, which indicates that MSTeams meetings on every topic were valuable.

The knowledge and skills acquired in the course are valuable and meaningful when they are applied in the faculty's daily work. Training is successful when it leads to the application of innovations, optimization of work, greater confidence in online teaching and ultimately to more effective teaching and learning. The results from the satisfaction scale reveal that the course responded to teachers' needs and concerns, although not to the desired extent four assertions received scores bigger than 4 (agree) but these assertions are directly linked with the immediate objectives of the course - understanding the functionality of the platform including administration of assessments and giving the confidence to teach online in Moodle. The lowest, though positive, score faculty gave to the assertion about positive change in views about applicability of e-learning in healthcare majors. Moralista and Oducado [1] report a similar reserved attitude towards e-learning in the context of the crisis caused by COVID-19. Although the learning objectives were achieved, the course failed to increase teachers' belief in the positives of computer-mediated instruction and motivate them for further e-learning initiatives. In the light of instructional design, motivational strategies are important and they should be frequent in instruction.

Like evaluation, satisfaction is statistically significantly dependent on computer skills level (Table 5.) and previous education in pedagogy (Table 6.). Lack of IT skills was identified as a barrier affecting e-learning in health sciences education in a systematic review by Regmi and Jones [12]. All grades but one in the satisfaction scale are less than 4 (agree) in the group of colleagues without pedagogic background, and all grades are bigger than 3.50 among the teachers who are competent in pedagogy. Pedagogically competent academic staff have been able to reap more benefits from the training, although the course has not been explicitly targeted at learners with pedagogical qualifications. The training also proved to be more effective for younger colleagues and those with more confidence in their computer literacy. The analysis of the audience in the design of such training should include criteria for pedagogical training and computer skills and these characteristics should be taken into account in the preparation of training materials and the selection of instructional strategies. According to Brinkley-Etzkorn technology and pedagogy should be integrated when training new online educators and this is not easy [9]. The results of this study indicate that in training designed to provide knowledge and skills for the manifestation of pedagogical techniques with new technological tools, faculty with pedagogic education managed to elicit more utility and value than teachers who have acquired pedagogical skills empirically during their service.

\section{Conclusion}

Both the evaluation of the course and the satisfaction with it are in the positive part of the evaluation scale, therefore we can assume that it has achieved its purpose. This training was created and conducted in an emergency to ensure for the faculty basic skills for successful teaching in an electronic environment in isolation due to the global pandemic. In the future, however, such training is expected not to be occasional, but regular and perhaps even mandatory. Therefore, objective feedback from the learners informs administration and stakeholders for ensuring adequate support for the staff in the form of e-courses. The major findings of this survey are:

1. The training of the academic staff in the learning content management system in which they teach enhances the direct transfer of knowledge and skills in teaching and provides a better notion of students' experience;

2. Confidence in computer skills and pedagogical qualification are strong predictors of the success of such training - both in terms of evaluation and achievement of educational goals, and in terms of satisfaction and increasing motivation to develop e-learning.

3. Training aimed at the teaching staff is beneficial when its design allows independent asynchronous learning, but there is also a synchronous component.

4. Training should be following the concept of micro-learning - to consist of short videos demonstrating particular skills directly related to the topic objectives. 


\section{References}

[1]. Moralista, R. B., \& Oducado, R. M. F. (2020). Faculty Perception toward Online Education in a State College in the Philippines during the Coronavirus Disease 19 (COVID-19) Pandemic. Universal Journal of Educational Research, 8(10), 4736-4742.

[2]. Button, D., Harrington, A., \& Belan, I. (2014). Elearning \& information communication technology (ICT) in nursing education: A review of the literature. Nurse education today, 34(10), 1311-1323.

[3]. Marzilli, C., Delello, J., Marmion, S., McWhorter, R., Roberts, P., \& Marzilli, T. S. (2014). Faculty attitudes towards integrating technology and innovation. arXiv preprint arXiv:1404.4334.

[4]. Puckree, T., Maharaj, S., \& Mshunquane, N. (2015). Status of usage of information communications technology by academic staff at a selected nursing training institution in South Africa. International Journal of Educational Sciences, 8(3), 511-519.

[5]. Gurley, L. E. (2018). Educators' Preparation to Teach, Perceived Teaching Presence, and Perceived Teaching Presence Behaviors in Blended and Online Learning Environments. Online learning, 22(2), 197-220.

[6]. Webb, L., Clough, J., O’Reilly, D., Wilmott, D., \& Witham, G. (2017). The utility and impact of information communication technology (ICT) for preregistration nurse education: A narrative synthesis systematic review. Nurse Education Today, 48, 160171.
[7]. Howard, S. K., Tondeur, J., Siddiq, F., \& Scherer, R. (2021). Ready, set, go! Profiling teachers' readiness for online teaching in secondary education. Technology, Pedagogy and Education, 30(1), 141-158

[8]. Alshorman, B. A., \& Bawaneh, A. K. (2018). Attitudes of Faculty Members and Students towards the Use of the Learning Management System in Teaching and Learning. Turkish Online Journal of Educational Technology-TOJET, 17(3), 1-15.

[9]. Brinkley-Etzkorn, K. E. (2018). Learning to teach online: Measuring the influence of faculty development training on teaching effectiveness through a TPACK lens. The Internet and Higher Education, 38, 28-35.

[10]. Israel, G. D. (1992). Determining sample size (Fact sheet PEOD-6). Gainesville, FL: University of Florida.

[11]. Yousaf, F., Shehzadi, K., \& Aali, H. A. (2021). Learning Management System (LMS): The Perspectives of Teachers. Global Social Sciences Review, VI(1), 183-196.

[12]. Regmi, K., \& Jones, L. (2020). A systematic review of the factors-enablers and barriers-affecting elearning in health sciences education. BMC medical education, 20(1), 1-18. 